\title{
Interleukin 12 Measurement
}

National Cancer Institute

\section{Source}

National Cancer Institute. Interleukin 12 Measurement. NCI Thesaurus. Code C74808.

The determination of the amount of interleukin 12 present in a sample. 